\title{
Farad per Meter
}

National Cancer Institute

\section{Source}

National Cancer Institute. Farad per Meter. NCI Thesaurus. Code C68912.

A SI unit of electric permittivity. 